\title{
Religious beliefs and entrepreneurial behaviours in Africa: a case study of the informal sector in Uganda
}

Article

Accepted Version

Namatovu, R., Dawa, S., Adewale, A. and Mulira, F. (2018) Religious beliefs and entrepreneurial behaviours in Africa: a case study of the informal sector in Uganda. Africa Journal of Management, 4 (3). pp. 259-281. ISSN 2332-2381 doi: https://doi.org/10.1080/23322373.2018.1516939 Available at https://centaur.reading.ac.uk/78850/

It is advisable to refer to the publisher's version if you intend to cite from the work. See Guidance on citing.

To link to this article DOI: http://dx.doi.org/10.1080/23322373.2018.1516939

Publisher: Taylor and Francis

All outputs in CentAUR are protected by Intellectual Property Rights law, including copyright law. Copyright and IPR is retained by the creators or other copyright holders. Terms and conditions for use of this material are defined in the End User Agreement.

www.reading.ac.uk/centaur 
Central Archive at the University of Reading

Reading's research outputs online 


\title{
Authors
}

1. Rebecca Namatovu*

Makerere University Business School

Email: rybekaz@yahoo.com

2. Samuel Dawa

Makerere University Business School

Email: samdawa@gmail.com

3. Adeyinka Adewale

Henley Business School, University of Reading

Email: adeyinka.adewale@henley.ac.uk

4. Fiona Mulira

Makerere University Business School

Email: fmulira@mubs.ac.ug

*Corresponding author

\begin{abstract}
Religion plays a major role in Africa's polity and its influence on the business landscape of the continent has been acknowledged in literature. This study contributes to the discourse by investigating and explaining how religious beliefs shape entrepreneurial behaviours in Uganda's informal sector. Using a qualitative methodology, we explored how entrepreneurs in the context use or adopt religious beliefs in their entrepreneurial activities. By spanning a diverse set of entrepreneurial activities in the informal sector- food vendors, fabricators, hawkers, and recyclers among others, we conducted 49 in-depth interviews. Our findings reveal that the entrepreneurs relied on their religious beliefs in defining and coping with a penurious context. Further to this, we explain how religious beliefs galvanize business behaviours and calibrate the entrepreneurial identities of respondents in the context. To facilitate future work, the study highlights how knowledge gaps in the cultural and social setup of the informal economy will produce new insights in entrepreneurship research. It concludes by guiding policy makers and educators to engage and involve faith based institutions in the entrepreneurship promotion agenda.
\end{abstract}

Key words: religious beliefs, entrepreneurial behaviour, informality, Africa 


\section{INTRODUCTION}

In severely resource constrained environments, entrepreneurs often have to make decisions with incomplete information frequently relying on previous experience and social networks. The motivations of these entrepreneurs in such difficult circumstances are typically influenced by stimuli outside the scope of typical business support institutions. One such motivation is the use of internal belief systems such as religious beliefs to help realize entrepreneurial outcomes (Guiso et al., 2006; McCleary \& Barro, 2006).

Modern management literature refers to the notions of 'religion', 'spirituality' and 'faith' as very distinct yet intricately intertwined concepts. Traditionally, as Penman, (2012) argues, spirituality had often been linked with religion, but more contemporary views of spirituality are generally humanistic and secular. Markow and Kelnke, (2005) for instance observed that there are more than seventy definitions of spirituality central to which is belief in a transcendent being often towards finding a higher purpose in life (Barker, 1995; Bullis, 1996; Netting, Thibault \& Ellor, 1990). Religion on the other hand is often conceptualised as belief in an organised set of practices and ethics within a faith community (Joseph, 1988; Furman \& Chandy, 1994; Cascio, 1998; Gotterer, 2001). Whilst both concepts may directly or indirectly refer to belief or faith in a supernatural entity, religion offers a defined framework within which belief is practiced but spirituality does not. Both notions are equally relevant and significant in the context of this study as religiosity and spirituality are deeply ingrained in Africa (Paris,1995) to the extent that it is for many people the modus operandi and raison d'etre for their lives (Ngunjiri, 2010). Therefore, given this sophisticated and almost inseparable link between religion and spirituality, this study adopts religion and religious beliefs as umbrella terms to imply spirituality as well. 
Religious beliefs are rarely privileged in the study of entrepreneurship despite their social and symbolic power (Dodd \& Gotsis, 2007). Particularly in Africa, the influence and role of religion in the meaning-making of entrepreneurs cannot be ignored in fully understanding the prevailing entrepreneurial mindset in the context. For instance, studies have shown that even when expectations are not rationally justified (from rational expectations theory: people make choices based on their rational outlook, available information and past experiences), entrepreneurs tend to expect positive outcomes. One reason often ascribed to this is the belief that the transcendent is able to affect the course of outcomes. Reid, Roumpi and O'Leary-Kelly (2015) highlighted how women entrepreneurs invoked spirituality when they faced personal and work related challenges. Other studies have shown that religious beliefs have an important role in shaping individual occupational decision-making and the institutional environment (Audretsch, Bönte \& Tamvada, 2013). Studies have also related faith-based identity, faith-induced practices, faith-filled vision and faith inspired cognitions in realizing entrepreneurial outcomes (Judge \& Douglas, 2013). However, what is absent from this body of research is how and why these variables translate into entrepreneurial behavior. We know relatively little about the role of religious values and practices that underpin our beliefs on broader social processes especially within the African context (Tracey, 2012). Therefore, the study seeks to answer the research question, "How do religious beliefs shape entrepreneurial behaviours?" Answering this question provides a more holistic interpretation of entrepreneurial behaviours within the African context. Furthermore, answering this research question extends the literature on entrepreneurial motivations through explaining this as a cultural influence on entrepreneurial behaviour. 


\section{RELIGION AND ENTREPRENEURSHIP: A REVIEW OF LITERATURE}

The influence of spirituality and religion within the field of entrepreneurship has been attracting increased scholarly attention (Candland 2000; Fernando 2007; Dana 2010; Tracey, 2012; Reid et al, 2015). The intersection of both concepts provides insights into how entrepreneurs' awareness of their personal, spiritual or religious values impact their business activities. A comprehensive review by Balog, Baker and Walker, (2013) identified that the religious or spiritual values of entrepreneurs influence their motivation and attitudes towards entrepreneurship, responsible business behaviour, psychological wellbeing and overall performance (such as profitability, sales turnover). Religion has also been ascribed to transcend the individual level of impact to the organisational level including organisation culture (e.g. having morning prayers at work), sociocultural environment (observing religious holidays and festivities) and personal networks (choice of business partners) (Ibrahim \& Angelidis, 2005; Silk, 2007; Baron, 2008).

Interestingly also, spirituality is often linked to how entrepreneurs make sense of the entrepreneurial process, such as opportunity recognition, new venture creation, as well as the operation and growth of their businesses (Dana, 2009; Balog, Baker and Walker, 2013). Rietveld and Van Burg, (2014) in a study of the role of religious beliefs in entrepreneurship among Dutch Protestants found that typical protestant employees construed their occupation as a calling from God and perceived it as a duty to add value to the society. Studies looking into the role of religion and spirituality in the entrepreneurial practices among Africans in the diaspora have also shown the 'church' plays a significant role in shaping the entrepreneurial beliefs of their members (Nwankwo, Gbadamosi and Ojo, 2012). These studies indicate that research on the relation between religion and entrepreneurship is instrumental in explaining the engagement of people in 
entrepreneurship. In this paper we argue that entrepreneurs rely on religious and spiritual resources for clarity and certitude in their entrepreneurial pursuits.

In the African context, the role spirituality and religion plays in the sense-making of entrepreneurs has also been documented. In a study on female entrepreneurs in Ghana by Reid et al, (2015), it was found that respondents used four key 'expressions of spirituality' in relation to their businesses namely: faith as verbal practice, faith as a coping tool, faith as an instrument tool and faith as God's direct guidance (Reid at al, 2015:10). Whilst, the use of religious phrases in everyday language speaks to the wider sociological connotation ascribed to religion in the African context, its deployment as a 'tool' in the successful running of enterprises implies it is not simply an 'add-on' but an essential foundational value to starting and running businesses successfully (Kinjerski and Skrypnek 2004 \& Morris and Schindehutte, 2005). Furthermore, given the permeable boundaries between religion and other areas of life in the African context, spirituality is easily deployed into sense-making in the entrepreneurial process. For instance, recognising a new business opportunity could be interpreted as God's direct guidance, as much as in addressing challenges faced in the areas of business, family, finance and human relations, the God-factor is often invoked as a means of appeasing anxieties and allaying fears (Reid et al, 2015). God is also often considered a resource provider in starting and scaling businesses. Therefore, in a context known for its institutional voids and frailties, belief in a transcendent being is considered an essential tool for navigating the tough economic landscape. Even though it has been noted that others operating in more supportive institutional environment also depend on religiosity their extent and use is less pervasive. It is the disabling environment that drives/ stimulates the use of religiosity in business.

In this study, we attempt to contribute to the existing discourse on the role of religion in entrepreneurship in Africa by looking at the Ugandan context. We build upon the work of Reid et 
al (2015) in attempting to review how entrepreneurs within the context leverage their religious values and beliefs in making sense of their entrepreneurial journeys which ultimately shapes their entrepreneurial behaviours as well.

\section{INFORMALITY AND THE RESEARCH CONTEXT}

Welter et al (2017) caution that when we narrow our view of entrepreneurship by focusing on the "valorized" (e.g. growth oriented, opportunity based, innovator, formal) and discard the "disparaged" (e.g. necessity based, informal, small business, imitator) perspectives, then entrepreneurship in some spaces will not be explored or understood. Moreover, Kiggundu (2002) showed that in Africa, a relatively understudied context, entrepreneurship is examined within the informal and formal sectors, around the individual entrepreneur, small and medium enterprises (SMEs), and family businesses among other forms.

In support of studying entrepreneurship outside strictly set boundaries, it has been argued that "given the context that Africa provides, which is one of a resource munificent environment steeped in a post-colonial setting with poverty and authoritarian governments, with recent sparks of reforms and progress, there would be the expectation that new theoretical contributions could emerge" (Devine \& Kiggundu, 2016: p367). Studies that have incorporated these nuances have provided richer understandings of entrepreneurship behaviour, for example, Vermeire \& Bruton (2016) showed how religious beliefs help entrepreneurs cope with uncertainties and that failing to create opportunities pulls entrepreneurs back into poverty. As such, exploring the informal sector has the potential to colour our perspectives of entrepreneurship within the continent and in the wider body of literature.

Informality, though not unique to sub-Saharan Africa, greatly defines the features of entrepreneurial activity in Africa (Schneider, 2005; Webb et al. 2009). Arguably, informality is 
not criminal activity but rather a market-based legal production of goods and services that are deliberately concealed from public authorities for reasons such as taxation and administrative regulation (Schneider, 2005). The final products are legitimate (Khavul \& Bruton, 2009) albeit the production and distribution may be illicit (Portes, Haller, \& Guarnizo, 2002). A more nuanced term is economic informality, which is entrepreneurial activity existing within informal institutions, but outside formal institutional boundaries (Webb et al., 2009). The latter can be represented by laws and regulations and the former by any norms and values that are accepted or benefit large groups in society.

Sub-Saharan Africa possesses a rich cultural mosaic underscored by political and economic challenges (Kuada, 2010). Most enterprises in sub-Saharan Africa are micro with less than five employees ( Fafchamps, 1996), unregistered or unlicensed, and typically do not pay taxes (Pretes, 2002). There is therefore a high economic informality (Khavul \& Bruton, 2009).

The lack of legal protection for participants in the informal economy spurs innovative strategies for self-protection and survival. Astute methods of operation such as pluriactivity (Rosa et al., 2006) or an octopus form of organisation ( Kiggundu, 2001; 2002) are adopted.. Entrepreneurs mitigate risk by having several small businesses as opposed to concentrating on growing one core business. In some cases, entrepreneurs deliberately compromise professionalism (Khavul et al., 2009) by using substandard factors of production, or devise operational technologies in order to survive at the expense of growth. Economic rationality is not usually sufficient to explain the behaviour of an entrepreneur in an African context, where there is deep embeddedness with spiritual, family and personal networks and many activities are highly informal hence the objective of this study. 
This study was conducted in Uganda. Uganda is a low-income country in sub-Saharan Africa that has a GDP per capita of 675.6 USD, with $19.5 \%$ of the population living below the poverty line of one dollar per day (World Development Indicators, 2016). Uganda has a substantial informal sector (Spring \& Rutashobya, 2009) that makes a significant contribution to its economic development. The informal economy in Uganda constituted 43\% of GDP (Cities Alliance, 2017). There are long and cumbersome administrative hurdles to business registration and licensing underscored by high-related costs. Uganda has a bureaucratic system, ranking the country $99^{\text {th }}$ in the world, with weak institutional structures and high corruption rates, with a ranking of 19 out of 25 in Africa (Lopez-Carlos, 2006). Many entrepreneurs operate in the informal economy, and remain unregistered, thereby avoiding government sanctions (Khavul et al.,2009) but experiencing long-term disadvantages that limit wealth creation. In this study we illuminate how beliefs shape entrepreneurial behaviour in a largely informal setting.

\section{Religion and Spirituality in Uganda}

Traditionally, Uganda like most African societies was organized around tribal groupings where members shared common cultures and beliefs. The societies always believed in some form of supernatural being that was responsible for socio-economic wellbeing. The gods ranged from naturally occurring physical structures such as lakes, mountains and trees to spirits that were evoked through intercession with witch doctors. Traditional African beliefs were associated with economic activity/benefit, wellbeing and success.

The first foreign group to introduce religion in Uganda were the Muslim clerics who arrived as early as 1844 . While these individuals sought trade partners, they informally converted a number

of individuals to Islam. They were followed by the Christian missionaries-Anglican in 1878 and 
Catholics in 1879. In additional to spreading Christianity, the missionaries fostered the sense of barter trade that eventually took root between the colonialists and the natives. Missionaries also promoted the growth of cash crops such as coffee and cotton that introduced large numbers of the population to the cash economy and also supplied the British industrialists with these raw materials.

Today Uganda is a predominantly Christian society with up to $84 \%$ of the population Christians (UBOS, 2014). There has also been an accelerated growth of the Pentecostal sub-sect that make up almost $11 \%$ of the population. The Pentecostal and born again movement has further enabled the spread of religious teachings to the most remote areas in the country.

It is common place for business owners to practice business according to his/her religious principles, this is evidenced by hiring people from one's faith, crafting missions according to one's religion, labelling products or services based on religious terms and associating the business with activities of the religion they subscribe to such as funding charity activities. Religious institutions and faith based organisations are spread all over the country, and are involved in a wide range of activities including education, health and other civic duties. Their print on the administrative, economic and political activity is significant. These beliefs play a role in entrepreneurial activity.

\section{METHOD}

The study adopted a qualitative methodology in exploring how beliefs shape entrepreneurial behaviour in the informal sector of Africa. Additionally, the study seeks to reveal interesting features of the context and the phenomenon being investigated. Forty-nine (49) interviews were 
conducted amongst entrepreneurs operating in the informal sector in Uganda. All entrepreneurs were involved in different business activities even though the phases of development and nature of activity varied significantly. Some were running micro enterprises, while others were involved in small business activity and very few owned medium sized enterprises that initiated as startups.

The study was involves three separate studies that were conducted in informal settings. One study was reviewing behaviour of entrepreneurs when resources are extremely constrained, the second study explored how women with disabilities managed to sustain their ventures and the third study investigated how sustainable enterprises use effectual processes to circumvent resource scarcity. In the separate studies it was highlighted that religiosity was a significant molder of entrepreneurial behaviour. So through triangulation of data from the various sources the study explored how religiosity was used in the context.

\section{Identification of the sample}

Uganda is one of the most entrepreneurial countries in the world, with one in every three people starting a business (Dawa, Balunywa, Namatovu, Orobia, Kyejusa \& Ntamu, 2014). However, the majority of enterprises in Uganda are small and do not employ anybody and as such they tend to remain small and informal (African Development Bank, 2013). Therefore to gain access to the entrepreneurs we often moved to known informal settings and reached out to entrepreneurs. Informality was characterized as "self-employed or salaried workers in small, precarious firms without a signed contract in compliance with labor regulations, and without access to protection against health and unemployment shocks, to savings for old age, to employment protection and to 
labor related benefits. They are mostly unskilled and operating in low productivity jobs, in marginal, small scale and often family-based activities" (Gaspirini and Tornarolli, 2007)

In developing our sample, we had the following criteria:

1. The entrepreneur needed to have started a business

2. They had to be managing the business.

3. They had to be in the informal sector "typical" businesses such as metal fabrication, food vending, hawking, trade, art and crafts among others.

4. They had to be willing to participate in the study and by being available for a face to face interview.

\section{Interview protocol}

Data was collected through semi structured face to face interviews. The data was collected in Kampala by three of the authors working along with three research assistants. This was done over a total of 60 days. The interviews were led by the authors and the research assistants provided support in observing the interview protocol such as gaining consent and recording the interviews. The research assistants received training about respondent confidentiality and practices of conducting a good interview. The length of the interview ranged from 45 minutes to 90 minutes. In addition, all members of the research team took field notes. The respondents were informed about the significance of anonymity and confidentiality of information and they were asked for permission to audio record and take notes during the interview. The audio recorded interviews were transcribed into written text by the research assistants.

Typically, all interviews started with stating the broad purpose of the study and by obtaining background information such as age, education and other details. The interview protocol consisted 
primarily of open ended questions that required the respondents to describe their entrepreneurial journey. The first main set of questions inquired about the business (e.g. where did the idea come from, barriers and enablers of business during the different phases of development, how they overcome barriers in the business and the environment). The narrations of the respondents alluded to the importance of faith, religion and beliefs in the entrepreneurial journey. This inspired the researchers to probe further on the subject. The interviews were mostly conducted in Luganda.

The next set of questions inquired about the status of the business, specifically, participants were asked to describe their business activity, number of employees, ownership, customers and competitors. The third section of the interview focused on the environment of business, how it deters or encourages entrepreneurship. The last section was largely about the future plans of the entrepreneur. Sample questions included: What are your business aspirations? How will your personal/ business aspirations survive the environmental challenges? All interviews ended with expression of gratitude for participation and respondents were given an opportunity to ask any further questions they had about the study.

The above described interview protocol generally guided how the interviews were conducted. However, like many other qualitative studies, adjustments and re-organisation did occur in situ. Eisenhardt (1989) argues that, that is acceptable because the natural flow of the conversation provides more interesting interviews. As such, there were some questions that spurred the participants more and therefore, at that stage adjustments were made. The researchers met often to talk about the independent fieldwork experiences and through these interactions it was revealed that religious beliefs were significant in the participants' entrepreneurial journey. The researchers found this interesting and thus probed further into the issue of religious beliefs in subsequent interviews. 


\section{Description of the sample}

The participants had varied demographic characteristics. The largest proportion of the respondents were female $75 \%$. Women mainly operate in the informal economy because they are less likely to meet formal sector requirements. 84\% of employed women in Sub-Saharan Africa, are in the informal sector (Benjamin, Beegle, Recanatini, Santini, 2014). The average time participants had operated the business was 13 years and the range was between 2 to 60 years. The enterprises were of varied sizes ranging from zero or one owner/employee to 30 employees. The majority of the participants referred to religious beliefs using significant words like God, Jesus Allah, Holy Spirit etc. Most of the respondents operated their ventures in the designated informal townships of Kampala, such Katwe, Kawempe, Owino and Kamwokya. They had a wide variety of business activity including metal fabrication, trade, charcoal stove making and small food stalls. Please refer to table1 for detailed outlook of the sample

Insert Table 1 About Here

\section{Coding}

The data collected by the different researchers including the field notes were transformed into a single folder. Then each case, was read to extract quotes that expressed or inferred to religion, religious beliefs or spirituality. The extracted quotes then created a new data set. The data were then coded inductively. We had a priori tentative specifications such as opportunity identification, support role, but we also allowed the data to drive the coding process. The process began with 
three of the authors jointly identifying the quotes that inferred to faith and myths. The authors had an extensive discussion about the possible research questions that the data could address. One author led the coding process and had extensive discussions with the rest of the authors as the coding went on. In order to attain dialogical inter-subjectivity, these meetings were held weekly (Kvale 1994, Gillespie et al, 2010). They were thus crucial in addressing the issue of reliability in qualitative research, because they promoted dialectical discourse and augmentation amongst the authors. The meeting allowed the coder to explain the codes in the transcribed sections, from which others critiqued or sought clarity. Codes were adopted only when at least three of the four authors found them agreeable. The outcome of the coding process was 100 codes which can be classified into 11 broad categories of ( Challenges, Childhood recollection, Disadvantage, Decision making, Growth aspiration, Market expansion, Motivation, Perseverance, Personality, Practices and Providing role ). The transcripts were organized and analyzed using Atlas ti software (Friese, 2014).

\section{Analysis}

Analyzing qualitative data could have challenges such as jumping to conclusions, disregarding disconfirming evidence and anything goes interpretation (Gephart, 2004; Suddaby 2006). Our study avoided such challenges by adopting the Gioia framework for analysis (Gioia \& Chittipeddi, 1991; Gioia \& Thomas, 1994; Corley \& Gioia, 2004). The main focus to the Gioia framework is to show that much of the world with which we deal with is socially constructed, and therefore studying it requires to capture the "(a) meaning for the people living that experience and (b) social scientific theorizing about that experience" (Gehman, et al, 2017:3). His framework is also motivated to devise a systematic methodology for inductive research to demonstrate rigour and scientific advancement in qualitative research (Gioia, Corley and Hamilton, 2013). This approach 
allows for a systematic presentation of both first order analysis resulting from informant-centric terms or codes and second order analysis based on the researcher centric concepts, themes and dimensions (Gehman et al, 2017).

We deemed this framework suitable because it captures the phenomenon (religion/ faith/ beliefs) as given by the participants. Of course working through this framework was not rigid. But essentially we aimed at having a data structure to explain how faith, religion and beliefs influence entrepreneurial behaviour. This analytical method was useful in providing a systematic overview of our thinking before we made any theoretical revelations. So we had $1^{\text {st }}$ order, $2^{\text {nd }}$ order codes and aggregate dimensions. We adopted an inductive analysis because we assumed that participants in the study are "knowledgeable agents" who can explain their thoughts, emotions, intentions and actions. So the $1^{\text {st }}$ order codes, basically foregrounded their views and the $2^{\text {nd }}$ order codes were our (researchers) concepts or themes as inspired from literature. Then the aggregate dimensions showed how the $2^{\text {nd }}$ order codes are linked. The ultimate aim was to develop an interpretive theory. Please refer to figure 1 for the data structure of beliefs shaping Entrepreneurial behaviour.

During the fieldwork, respondents often referred to faith, religious beliefs, cultural beliefs and traditions. Therefore, additional analysis was done to explore the role of religious beliefs in the entrepreneurial behaviour of the participants. We ensured that we had identified all the possible references to beliefs in our initial coding, we therefore conducted a word search in Atlas ti. using 20 religious belief related words. (for example, Holy spirit, Bible, God, Jesus, Angel, blessing, church, ministry, calling, mosque, Allah, traditional healer, spirits, jajas, jujus, witchcraft). A total of fifty two interviews were identified as having used at least one of the terms listed. However, in three interviews reference to religion and spirituality was not related to individual or business context but rather a general mention. (e.g. we are near a mosque, saved people don't believe in my 
work ). These were not included in the study. Then two authors conducted an in-depth content analysis of the text of 49 interviews that included at least one of the belief related references. They independently coded these expressions and discussed each coded passage until consensus was reached. The outcome of this coding revealed the context and behaviour that was attributed to religious beliefs.

\section{RESULTS}

The coding highlighted three major themes, i.e. framing the business context, defining business practices and stimulating entrepreneurial identity. Below we explain each theme.

\section{Framing the business context}

We explored the context within which religious beliefs were framed among the participants. Our understanding of the settings in which the various belief expressions were attributed by the entrepreneurs in informal enterprises, was derived from $1^{\text {st }}$ order and $2^{\text {nd }}$ order codes as shown in figure 1. The analysis established three meta constructs that display how religious beliefs are constructed by the informal sector entrepreneurs as follows: a) Sense making for being disadvantaged b) platform for elevation and c) source of provision. The participants' business context was framed by their religious beliefs.

Insert Figure 1 About Here 
Belief as a sense-making tool for being disadvantaged. The participants attributed their business and personal disadvantages to belief. They argued that current and previous prejudices were a result of "beliefs". A number of the women entrepreneurs with disabilities expressed that their personal prejudices and hindrances were due to "beliefs". Their explanation of the social stigma (such as discrimination and disrespect) and inadequate support (such as inability to get help in business) was because they felt beliefs had predestined them to be as such.

"I am a woman. I never wanted to be a disabled person but maybe that is how God planned it to be upon my life"

"There is no one in this area that sells charcoal apart from me so I wondered why people were bewitching me.... . Many people have discouraged..., saying I will not manage working from this place”

The business challenges that were attributed to beliefs were in accordance to the predicaments that entrepreneurs faced while conducting business. These relate to either failure to make profits in a business transaction or regulatory enforcement that dictated the change in business products or location.

"Then we were chased away from the first location where business was booming, that was a blow, up to now, I don't know why God did it”.

"But of course it not easy, this is a Muslim family, every child has a different mother moreover, I'm one of the young ones, so it was challenging....my brothers would intercept customers and down cut my prices" 
However, other entrepreneurs were more positive in their outlook and perceived beliefs as a platform of elevation. They attributed most of their business or personal achievements to beliefs. While the meaning and extent of success varied for many of the entrepreneurs, they expressed it as a level of contentment.

"She mistreated me and reached an extent of trying to poison me, but God helped and I became what I am today"

"I'm a faithful roman catholic, the Holy Spirit has made me successful in what I do"

These accounts were mainly made in regard to the entrepreneur's life. In business terms, religion was highlighted as a key resource that supported idea generation, business skills development and decision making.

"I have a poor peasant background and therefore my being genius or innovative is attributed to God"

"we believe that God is there he is the reason we live so he gives us the wisdom he gives us the life that we breathe he gives us everything..."

Another common perception to beliefs was, it was a source of provision. The entrepreneurs in the informal setting were generally mindful of the fact they their space was less privileged. So their ability to be better than those around them was perceived as an achievement. Their reference to 
beliefs as a provider was highlighted with a sense of gratitude. This view was used in reference to mainly their business activity.

"God helped me to get capital and when I started this business I managed to get money and look after my children, I pay for their school fees and buy food at home" "It's like God gives you that one extra talent naturally. I didn't study, naturally I think I can market something and convince someone to buy something”,

"God loves me...we have been able to get these things, that fridge has boosted me a lot and even customers that keep coming from these neighboring university and church"

\section{Defining business practice}

Beliefs were highlighted as defining business practices. The entrepreneurs explained that the manner in which they did business was triggered by their faith. This was evident in the various stages that their ventures had been through. That is, some practices were crucial for the ideation phase while others were useful for the implementation and survival of their ventures. We find that beliefs defined business practices in two ways, as a form of expression and a descriptor of business norms (See figure 1).

The entrepreneurs referred to their beliefs as having caused them to engage in a particular type of business. The view implies that they would ordinarily not opt to engage in business had they not had the beliefs they poses. The beliefs are thus expressed through their business activity

"I get a little (minimal profits) but I know God wants me here and I am serving God and I am doing God's will so that confidence is in me" 
"My business has helped me to spread the gospel, when people buy the rosaries and pray with them, they get close to their God. This is helping the whole mission of God"

The other aspect of defining business practice was the view that beliefs were descriptors of business norms. Therefore, beliefs determined the norms and customs of conducting business activity. For instance the credit policies they used, the choice of customers or markets to interact with and the attitudes to business success. In general, these fundamental business functions were hinged on the entrepreneur's beliefs.

"When I have a debtor that is really bothering me and he is not telling me the truth. I say

God deal with him because I really need my money and God has come through for me. God makes them pay when I need my money. So yes he has made me who I am in business today"

“I have learnt that people don't want to see others prospering. So I never sell goods on credit. I make exceptions after seeking God to guide me. Or when God specifically tells me to sell on credit to some people”

\section{Stimulating entrepreneurial identity}

Entrepreneurship is known to occur in situations where risks and opportunities are not clearly defined. While it is typical that the entrepreneur gathers a lot of information, analyses situations and could consult many stakeholders before making a major decision, in these cases, the entrepreneurs opted to seek guidance of the super natural. Religious beliefs in these circumstances provide the necessary impetus for one to form and manage a venture. They are believed to stimulate the entrepreneurial identity. The findings portray a smooth link between 
how the stimulated entrepreneurial identity determines the business norms and practices.

Stimulating the identity was expressed two fold, a) by catalyzing entrepreneurial habits b) through honing business traits as shown in figure 1

In catalyzing entrepreneurial habits, the respondents revealed that their business formation and practice were based on their beliefs. For example, they relied on beliefs to make major decisions with expressions such as, "I was waiting to hear God's view on the issue, or when it was confirmed in my spirit, I was ready to act". What is portrayed, is that entrepreneurial or business personalities were realized or confirmed from beliefs. "Basically you need to have these Christian values as you do business",

Additionally, innovative ideas were authenticated by belief in God. As one respondent stated,

“That's definitely God's intervention for someone to be able to innovate a product from a material which has been there for centuries. Remember Moses from the Bible he was actually in a basket made out of papyrus"

Thus the rejuvenated or re-born entrepreneurial habits (entrepreneurial habit catalyst) reinforced their desire to express themselves as entrepreneurs with belief (forms of expression).

"I have never done anything in my life without consulting God and actually he is the only reason I am who I am today and even when things start to be hard, I ask him, have you left me? God is primary, everybody else is secondary"

"But within the night...I came to my senses and I said God if you desire that I will be teaching children and that is your plan for me, okay Lord I accept, just like that and the big thing on my heart rolled and fell off and I gained peace and I went down and sleep took me immediately." The respondents indicated that their abilities as entrepreneurs were refined by their beliefs (honing business practices). This attribute emphasizes the rationale that beliefs were used to define 
business norms and customs (descriptor of business norms). There were testimonies of how boldness and confidence in starting and maintaining ventures was invigorated by faith. Confidence is an external manifestation of one's perception of self-worth. It is a reflection of one's faith in his/her abilities. Confidence is important for entrepreneurs, who have nothing other than their own resources to fall back on. Confidence is not only important in making the decision to engage in entrepreneurship but it is also important in the acquisition of resources and the seeking of markets. The entrepreneur must have confidence in his product and his production processes to deliver outputs that will satisfy his intended market. The confidence manifested itself in their ability to learn and to execute entrepreneurial tasks.

"It is God who gave me that confidence because he spoke, remember? God didn't want me to just sit there and wait for support. He directed to me to start this business. When he directs you, you are sure that he will work with you and all will be well"

“People call me jaja, I have a special skill as a traditional healer. Now I'm being consulted to make cultural family planning methods for women. My version will not have side effects, have powers from my forefathers “

Another common argument was that beliefs fuelled a drive for perseverance in business. Dealing with hardships is an unavoidable part of the entrepreneurial journey. The turbulence in informal settings eliminates potential and present entrepreneurs. Having to deal with a number of individuals and institutions the entrepreneur's path is paved with uncertainties of different types. Therefore perseverance can equip the entrepreneur with the tenacity needed to overcome volatility. Religious beliefs set high levels of perseverance. Entrepreneurs have to bear circumstances that are uniquely challenging compared to the ones one would encounter in employment. Moreover, the volatility in an informal and resource constrained environment is rapid and frequent. 
"However tough it gets; I am sure that my God will be there for me. Every, business owner must be strong because there is nothing that happens without God knowing it. I advise them to be strong in whatever circumstances"

"My salvation teaches me to bear burdens because God will deliver me. Even while I suffered those setbacks I knew with God on my side I would succeed"

The above quotes show that regardless of the unbearable circumstances, the entrepreneur was able to work towards achieving his/her aim. Beliefs provided the ability for sustained action in the face of hardships among other things.

\section{DISCUSSION}

Our findings suggest that religious beliefs were critical to the sense-making of entrepreneurs in the informal business context. Thus, our findings are consistent with Reid et al, (2015) who found that religious beliefs served as both a 'coping tool' and an 'instrumental mechanism' for these entrepreneurs. In leveraging religion as a coping mechanism, most of our respondents deferred very easily to their religious beliefs in rationalizing difficult personal and business issues such as their disability, tough business context, and interpersonal conflicts with others within their communities. Likewise, success in business was rationalized as an act of God, which often implied religious beliefs were also considered platforms for elevation. Hence, the dichotomy of religious beliefs as a coping mechanism implies that there seemed to be a religious explanation for every circumstances beyond mere verbal expressions but a deep seated belief in the role of the transcendent in their daily situations. The reliance on God for provision of key resources played out very similarly to women entrepreneurs in Ghana (Reid et al, 2015). As such, religious beliefs 
are held as crucial to access 'supernatural supply' for financial increase and the acquisition of key assets.

Therefore, the above findings show the centrality of beliefs at the onset of the entrepreneurial journey. While the beliefs are used to explain the individual's circumstances, they also serve as a source of insight, resources and fortitude in the event of encountering challenges. Previous literature has dwelt on the role of beliefs in providing resources, access to markets from fellow believers and informing perseverance. Absent from these studies is an explanation of how the entrepreneurs tend to rely on these beliefs. In this paper we attribute this to a lens that the entrepreneur uses to explain their current circumstances which translates into the resource acquisition and perseverance. The importance of this finding is that it broadens our understanding of factors outside the control of the entrepreneur and how the entrepreneur reconciles his/her independence with these. Perseverance is discussed later in the paper. Take it out here to preserve space.

In 'defining' business practice, religious belief served as the basis and guide for inter-personal interactions and business policies such as credit sales, discounts, and profit margin. Based on these practices, entrepreneurs in the context of this study typically use their businesses as an avenue to promote their religions. In other words, religion and business are so intricately interwoven that entrepreneurs in this context considered their businesses and business practices as the face of their religious beliefs to the wider community. This sense of commitment to religious values serves as a catalyst for the different forms of business behaviours, which further echoes our earlier sentiment that in these contexts, religious values are deep-seated beliefs at the core of every decision made. 
Thus, the use of entrepreneurship to express one's faith is common practice. The results show that the entrepreneur did not focus exclusively on the profit motive but also sought to pursue their faith ideals in the business. This was further emphasized in using the faith ideals as a basis for defining business practices. This is important because it justifies the broadening of the inquiry into the nature of decision making in entrepreneurship beyond the focus on cognitions.

This finding improves our understanding of why people engage in entrepreneurship because it highlights how entrepreneurs express and explore their beliefs. It advances previous studies such as Dodd and Gotsis (2007) that revealed that how business and beliefs are reinforcing. Businesses are used to spread beliefs and yet beliefs provide resilience in business. Beyond this, by relying on a value system established in long held beliefs, decision-making is easier and the entrepreneur may tolerate less than ideal outcomes for as long as the decisions were based on deep held values. Consequently, it follows that entrepreneurs in the context of this study considered their religious beliefs as the stimulator of their entrepreneurial identity. Erikson, (1964) referred to identity as the very essence of being that provides an answer to the question - Who am I? Within the context of this study, religious beliefs were discovered to influence entrepreneurial identity in two major ways: as a catalyst for entrepreneurial habits and in honing practices for business. Central to both of these is the concept of values. The deference to religious beliefs as the source of entrepreneurial values speaks to the fact that religion is central to the identity of entrepreneurs in this context. It sums up who they are and what they do. This type of deep seated belief can be explained from a moral identity theory (Aquino and Reed, 2002). According to this theory, values that are held as central to one's belief constitute a moral identity such that given any situational cue, these values are triggered into action thereby informing sense making and subsequent choices made. On a deeper level, the concept of moral identity in the case of these 
Ugandan entrepreneurs explains why many tend to show a lot of resilience in the face of adversity, using their faith in confidence building and in instilling boldness to take on tasks. The results show that the sense of how to do business right is drawn from the personal belief system of the entrepreneur. Further to this, the finding provides an explanation for how personal beliefs may inform entrepreneurial action by acting as a catalyst for the realization of known entrepreneurial traits (Refer to figure 1). In this way the finding is important as it helps explain how beliefs are used to frame external realities. Previous research has shown that the faith-based identity of the entrepreneur is related to the motivation to engage in the start-up process (Judge \& Douglas, 2013). In this study we advance this theorization by showing the role of this identity in fostering entrepreneurial activity beyond the start-up phase. It also improves our understanding of what values motivate entrepreneurs to contend with hardships.

\section{Research contribution}

This study builds on previous studies on the role of religion, spirituality and faith in entrepreneurship to explore how individual's beliefs shape their entrepreneurial behaviour. The contribution this paper makes is that beliefs shape entrepreneurial behaviour by framing the context of entrepreneurship, through stimulating entrepreneurial identity and by defining business practice.

Beliefs are used to initiate entrepreneurial actions such as boldness, perseverance and confidence. However, despite these three constructs being a central feature of entrepreneur's self-concept and behaviour orientation, they have hardly been discussed in literature on religion and faith in entrepreneurship prior to this study. Self-confidence is the trust in ones' abilities that drives them to seek out opportunities that help their business, in often highly constrained and restricted 
environments. It is through perseverance that these entrepreneurs are able to exercise control over events to accomplish their desired goals. It is their tolerance for uncertainty, or lack thereof, which enhances or inhibits their business motivation and problem-solving efforts. Therefore in a highly resource constrained environment, boldness, self-confidence and perseverance are used as business support mechanisms. In an era of infrastructural and institutional break down, beliefs support ingenuity. Entrepreneurs' beliefs facilitate learning and development of entrepreneurial competencies. .

On the other hand, faith is a 'defining business practice' through a) being a platform of expression, where businesses are initiated to affirm belief in God and b) a descriptor of norms and practices, for example, tying growth aspirations to belief. Therefore, in informal settings, the plethora of challenges are mitigated by faith, religion and beliefs and yet faith also dictates management practices and customs. The findings in this study therefore offer several important insights which broaden our understanding of how factors outside the control of the entrepreneur influence behaviour and how the entrepreneur reconciles his/her independence with these.

The paper further contributes to literature by explaining how beliefs are used to frame external realities. Informal sector entrepreneurs in the Ugandan context perceive beliefs as the basis of both favourable and unfavourable outcomes in their entrepreneurial journey. These outcomes have an influence on their actions affecting their tendency to generate ideas, implement them and grow their businesses in resource-constrained environments. The study thus improves our understanding of what values motivate entrepreneurs to contend with hardships. 
In summary, the absence of formal structures and high information asymmetry occasioned by poor infrastructure and low education levels creates a situation where informal sector entrepreneurs operating in resource constrained environments have to rely on alternative mechanisms for decision making. This study sheds more light on how entrepreneurs act in the absence of concrete information and therefore helps us understand how non-rational mechanisms are employed by entrepreneurs.

\section{Suggested areas for further research}

This paper highlights some interesting issues that could form subjects for further research. Research questions include: When the environment is informal and resource constrained, how can entrepreneurs' apply their beliefs that are at the heart of their decision making for enterprise growth? What types of enterprises do entrepreneurs who rely on beliefs start?

The strong religion and faith culture of business environments in Africa suggest the need for evaluative studies that can assess the direct impact of an entrepreneur's beliefs on enterprise sustainability.

Research on how religious beliefs contribute to entrepreneurial performance would be useful to highlight whether religious beliefs impact or influence business effectiveness.

In addition, further studies should investigate the understanding of beliefs in other non-resource constrained entrepreneurial contexts and should include larger samples to test for generalisability. A large-scale longitudinal study of entrepreneurs' beliefs over time in the same business sectors would be necessary to test the research results with a wider population. 


\section{Limitations}

The study relied on a small sample of cases whose findings may not be generalizable to the population, however, the study did not seek generalisability to the population rather to theory. Additionally, the study was based on data collected from three separate studies, which may be subject to bias since participants have more control over the content of data collected. However, this was mitigated by a triangulation of data sources and a thorough coding process. Therefore, the in-depth and detailed evaluation of beliefs and entrepreneurial behaviour as they relate to entrepreneurs in the informal sector provide some lessons that are applicable beyond this study as discussed in results and discussion sections. Another drawback of this study is that we did not collect any data on entrepreneurial performance and therefore cannot relate religious beliefs to business effectiveness or success. Finally, since this was a qualitative study, the interpretation of data is prone to subjective explanations, which implies the same dataset can result in different conclusions depending on the views of the researcher. We were however able to minimise such subjective interpretations by allowing all colleagues involved in this process access to the data and full involvement in the coding process. Through intense discussions around the codes generated, how they were generated and their meanings, we were able to synchronise diverse perspectives and agree on the final codes categories generated from the data.

\section{CONCLUSION}

This study set out to explain how beliefs, especially religion inclined beliefs shape entrepreneurial behaviours amongst entrepreneurs in the informal sector in Uganda. It builds on the notion that the entrepreneur is not an isolated, economically driven individual but relies on religion to further his/her aims. What makes this study crucial to the ongoing discourse on the role of religion and spirituality in the sense-making of entrepreneurs in tough, informal contexts in Africa is that it 
provides an understanding of how religious beliefs, which are outside the control of the entrepreneur influence their behaviour. It further elaborates on how the entrepreneur reconciles his/her independence with religious beliefs.

The study highlights how religious beliefs are used to frame external realities. Beliefs are perceived as the basis of both favourable and unfavourable outcomes in their entrepreneurial journey. In resource constrained informal settings, the tendency to generate ideas, implement them and grow business ventures can be attributed to religious beliefs. This paper therefore improves our understanding of what values motivate entrepreneurs to contend with hardships.

The inefficient institutional framework that typifies sub-Saharan Africa, implores these entrepreneurs to lurch for resources and information elsewhere. They use none rational mechanisms to create, manage and sustain their ventures. On this basis, we can conclude that religion is central to the identity of entrepreneurs in the informal entrepreneurial context, which in turn influences how they make sense of daily business challenges.

This research contributes to literature in three important ways. First, the research makes a theoretical contribution to the understanding of how religious beliefs of entrepreneurs operating in informal and resource constrained settings frame their business context and define their business practices. Second, and consequently, it contributes to a greater understanding of how when institutions are severely limited and inefficient, religion spurs an entrepreneurial identity. Finally, we contribute to the understanding of the power of religion in informal sector entrepreneurship. This article provides an insight into the cultural and social complexities that are prevalent in informal settings. 
This study is useful for policy makers who aim at facilitating the entrepreneurial ecosystem. The study highlights how faith based organizations are important institutions for entrepreneurship development. Therefore, policy makers need to forge mechanisms that actively engage faith based organizations in the national entrepreneurship agenda.

The study findings also have implications for entrepreneurship educators. Given that informality is pervasive in African settings and religion frames the entrepreneurship context, then educators need to incorporate insights and intimate knowledge of how religiosity is impactful on entrepreneurship. The entrepreneurship training curricula should have a focus on religiosity.

\section{REFERENCES}

African Development Bank, (2013). Recognizing Africa's Informal Sector. African Development Bank Group. Retrieved from http://www.afdb.org/en/blogs/afdbchampioninginclusive-growth-across-africa/post/recognizing-africas-informal-sector$\underline{11645 /}$

Aquino, K. and Reed, I.I. (2002).The self-importance of moral identity. Journal of personality and social psychology, 83(6), p.142

Audretsch, D. B., Boente, W., \& Tamvada, J. P. (2013). Religion, social class, and entrepreneurial choice. Journal of Business Venturing, 28(6), 774-789.

Balog, A.M., Baker, L.T. and Walker, A.G., (2014) Religiosity and spirituality in entrepreneurship: a review and research agenda. Journal of management, spirituality \& religion, 11(2), pp.159-186.

Baron, J., 2008, September. Cultural values and beliefs from an educational perspective in the Arab world. In Proceedings of the education research group of Adelaide (ERGA) conference (pp. 1-12).

Bellu, R., \& Fiume, P. (2004). Religiosity and entrepreneurial behavior: an explanatory study. International Journal of Entrepreneurship and Innovation, 5(3), 191-202

Benjamin, N., Beegle, K., Recanatini, F. \& Santini, M. (2014). Informal Economy and the World Bank, World Bank Research Working Paper \# 6888.

Candland, C., 2000. Faith as social capital: Religion and community development in Southern Asia. Policy Sciences, 33(3-4), pp.355-374. 
Cascio, T. (1998) Incorporating spirituality into social work practice: A review of what to do. Families in Society: The Journal of Contemporary Social Services, 79(5), pp.523-531.

Cities Aliance, (2017). Transformational Change in Sub-Saharan Cities. The Role of Informality in the Hybrid Economy of Uganda. Retrieved from http://www.citiesalliance.org/sites/citiesalliance.org/files/Role\%20of\%20Informality\%20U ganda.pdf

Corley, K. G., \& Gioia, D. A. (2004). Identity ambiguity and change in the wake of a corporate spin-off. Administrative Science Quarterly, 49, 173-208.

Dana, L.P. ed., 2010. Entrepreneurship and religion. Edward Elgar Publishing.

Dawa, S., Balunywa, W., Namatovu, R., Orobia, L., Kyejjusa, S., \& Ntamu, D (2014). Global Entrepreneurship Monitor Uganda Executive Report, Makerere University Buiness School Kampala

Devine, R. A., \& Kiggundu, M. N. (2016). Entrepreneurship in Africa : Identifying the Frontier of Impactful Research. Africa Journal of Management, 2(3), 39-380. http://doi.org/10.1080/23322373.2016.1206802

Diomande, M. (1990). Business Creation with Minimal Resources: Some lessons from the African Experience. Journal of Business Venturing, 5(4), 191-200.

Dodd, S.D. and Gotsis, G.(2007) The interrelationships between entrepreneurship and religion. The international journal of entrepreneurship and innovation, 8(2), pp.93-104.

Eisenhardt, K. M. (1989). Building Theories from Case study Research. Academy of Management Journal, 14(4), 532-550.

Eisenhardt, K. M., \& Graebner, M. E. (2007). Theory Building from Cases: Opportunities and Challenges. Academy of Management Journal, 50(1), 25-32.

Erikson, E.H., 1964. A memorandum on identity and Negro youth. Journal of Social Issues, 20(4), pp.29-42.

Fafchamps, M. (1996). The Enforcement of Commercial Contracts in Ghana. World Development, 24(3), 427-448. http://doi.org/10.1016/0305-750X(95)00143-Z

Fernando, S., (2007). Spirituality and mental health across cultures. Spirituality, values and mental health, pp.59-66.

Friese, S. (2014). Qualitative data analysis with ATLAS.

Furman, L.D. and Chandy, J.M. (1994). Religion and spirituality: A long-neglected cultural component of rural social work practice. Human Services in the Rural Environment, 17(3/4), pp.21-26. 
Gaspirini, L. and Tornarolli, L., (2007). Labor informality in Latin America and the Caribbean: Patterns and trends from household survey microdata, CEDLAS working Paper $n^{\circ} 46, \mathrm{La}$ plata, Centro de Estudios Distributivos Laborales y sociales.

Gehman, J., Glaser,L.V., Eisenhardt, M. K., Gioia, D., Langley, A., and Kevin G. Corley, G.K. (2017). Finding Theory-Method Fit: A Comparison of Three Qualitative Approaches to Theory Building. Journal of Management Inquiry, 1-18

Gioia, D. ., Corley, K. G., \& Hamilton, A. L. (2013). Seeking Qualitative Rigor in Inductive Research: Notes on the Gioia Methodology. Organizational Research Methods, 16(1), 1531. http://doi.org/10.1177/1094428112452151

Gioia, D. A., \& Chittipeddi, K. (1991). Sensemaking and sensegiving in strategic change initiation. Strategic Management Journal, 12, 433-448.

Gioia, D. A., \& Thomas, J. B. (1996). Identity, image, and issue interpretation: Sensemaking during strategic change in academia. Administrative Science Quarterly, 41, 370-403.

Gotterer, R. (2001). The spiritual dimension in clinical social work practice: A client perspective. Families in Society: The Journal of Contemporary Social Services, 82(2), pp.187-193.

Guiso, L., Sapienza, P., \& Zingales, L. (2006). Does culture affect economic outcomes? Journal of Economic perspectives, 20(2), 23-48.

Hmieleski, K. M., \& Baron, R. A. (2009). Entrepreneurs' optimism and new venture performance: A social cognitive perspective. Academy of management Journal, 52(3), 473-488.

Ibrahim, N.A. and Angelidis, J.P. (2005). The long-term performance of small businesses: are there differences between "Christian-based" companies and their secular counterparts?. Journal of business ethics, 58(1-3), pp.187-193.

Joseph, M.V. (1988). Religion and social work practice. Social Casework, 69(7), pp.443-452.

Judge, W. Q., \& Douglas, T. J. (2013). Entrepreneurship as a leap of faith. Journal of management, spirituality \& religion, 10(1), 37-65.

Khavul, S., Bruton, G. D., \& Wood, E. (2009). Informal family business in Africa. Entrepreneurship Theory and ..., (817), 1219-1238. Retrieved from http://onlinelibrary.wiley.com/doi/10.1111/j.1540-6520.2009.00342.x/full

Khayesi, J. N. O., \& George, G. (2011). When does the socio-cultural context matter? Communal orientation and entrepreneurs' resource accumulation efforts in Africa. Journal of Occupational and Organizational Psychology, 84(3), 471-492. http://doi.org/10.1111/j.2044-8325.2011.02029.x

Khayesi, J. N. O., George, G., \& Antonakis, J. (2014). Kinship in Entrepreneur Networks: Performance Effects of Resource Assembly in Africa. Entrepreneurship Theory and 
Practice, 1323-1342. http://doi.org/10.1111/etap.12127

Kiggundu, M. N. (2001). Management in Uganda. In M.Warner (Ed), Internaiona encyclopedia of business and management ( $\left.2^{\text {nd }} \mathrm{Ed}\right)$ pp (6611-6618) London: Thomson Learning Business Press

Kiggundu, M. N. (2002). Entrepreneurs and Entrepreneurship in Africa: What is Known and what needs to be Done. Journal of Developmental Entrepreneruship, 7(3), 239-258.

Kinjerski, V.M. and Skrypnek, B.J., (2004). Defining spirit at work: Finding common ground. Journal of organizational change management, 17(1), pp.26-42.

Kuada, J. (2010). Culture and leadership in Africa: a conceptual model and research agenda. African Journal of Economic and Management Studies, 1(1), 9-24. http://doi.org/10.1108/20400701011028130

Lopez-Carlos, A. (2006). Executive Summary World Economic Forum.

Markow, F. and Klenke, K., 2005. The effects of personal meaning and calling on organizational commitment: An empirical investigation of spiritual leadership. International Journal of Organizational Analysis, 13(1), pp.8-27.

McCleary, R. M., \& Barro, R. J. (2006). Religion and economy. Journal of Economic Perspectives, 20(2), 49-72.

Morris, M., Schindehutte, M. and Allen, J., (2005). The entrepreneur's business model: toward a unified perspective. Journal of business research, 58(6), pp.726-735.

Netting, F.E., Thibault, J.M. and Ellor, J.W., (1990). Integrating content on organized religion into macropractice courses. Journal of Social Work Education, 26(1), pp.15-24.

Paris, P.J., (1995). The spirituality of African peoples: The search for a common moral discourse. Fortress Press.

Penman, J. (2012). Motivations driving spiritual engagement based on a phenomenological study of spirituality amongst palliative care clients and caregivers. Journal of Nursing Education and Practice, 2(3), 135.

Portes, A., Haller, W. J., \& Guarnizo, L. E. (2002). Transnational entrepreneurs: An alternative form of immigrant economic adaptation. American Sociological Review, 67(2), 278-298.

Pretes, M. (2002). Microequity and Microfinance. World Development, 30(8), 1341-1353. http://doi.org/10.1016/S0305-750X(02)00044-X

Reid, M., Roumpi, D. and O'Leary-Kelly, A.M., (2015). Spirited women: The role of spirituality in the work lives of female entrepreneurs in Ghana. Africa Journal of Management, 1(3), pp.264-283.

Rosa, P. J., Kodithuwakku, S. S., \& Balunywa, W. (2006). Entrepreneurial motivation in developing countries: what does "necessity" and "opportunity" entrepreneurship really 
mean? Frontiers of Entrepreneurship Research, 26, 1-14.

Schneider, F. (2005). Shadow economies around the world: what do we really know? European Journal of Political Economy, 21(3), 598-642.http://doi.org/10.1016/j.ejpoleco.2004.10.002

Silk, M., (2007). Defining religious pluralism in America: A regional analysis. The ANNALS of the American academy of political and social science, 612(1), pp.62-81.

Spring, A., \& Rutashobya, L. K. (2009). Gender-Related Themes in African Entrepreneurship: Introduction to the Articles. Journal of African Business, 10(1), 1-10. http://doi.org/10.1080/15228910802701270

Suddaby, R., Bruton, G. D., \& Si, S. X. (2015). Entrepreneurship through a qualitative lens: Insights on the construction and/or discovery of entrepreneurial opportunity. Journal of Business Venturing, 30(1), 1-10. http://doi.org/10.1016/j.jbusvent.2014.09.003

Tracey, P., (2012). Religion and organization: A critical review of current trends and future directions. Academy of Management Annals, 6(1), pp.87-134.

Wambura Ngunjiri, F., (2010). Lessons in spiritual leadership from Kenyan women. Journal of Educational Administration, 48(6), pp.755-768.

Webb, J. W., Ireland, R. D., \& Sirmon, D. G. (2009). You Say Illegal, I say Legitimate: Entrepreneurship in the Informal Economy. Academy of Management Review, 34(3), 492510.

Webb, J., Bruton, G. D., Tihanyi, L., \& Ireland, R. D. (2013). Research on entrepreneurship in the informal economy: Framing a research agenda. Journal of Business Venturing, 28(5), 598-614. http://doi.org/10.1016/j.jbusvent.2012.05.003

Welter, F. (2011). Contextualizing Entrepreneurship-Conceptual Challenges and Ways Forward. Entrepreneurship Theory and Practice, 35(1), 165-184. http://doi.org/10.1111/j.15406520.2010.00427.x

Welter, F., \& Smallbone, D. (2011). Institutional Perspectives on Entrepreneurial Behavior in Challenging Environments. Journal of Small Business Management, 48(1), 107-125.

Welter, F., Baker, T., Audretsch, D. B., \& Gartner, W. B. (2017). Entrepreneurship - A Call for Entrepreneurship Research to Embrace Entrepreneurial Diversity. Entrepreneurship Theory \& Practice, 311-321. http://doi.org/10.1111/etap.12258

Welter, F., Smallbone, D., \& Pobol, A. (2015). Entrepreneurial activity in the informal economy : a missing piece of the entrepreneurship jigsaw puzzle. Entrepreneurship \& Regional Development, 27(5-6), 292 


\begin{tabular}{|c|c|c|c|c|c|c|}
\hline $\begin{array}{l}\text { Table 1: } \\
\text { Sample e } \\
\text { Descrition }\end{array}$ & & & & & & \\
\hline $\begin{array}{l}\text { Gender of } \\
\text { Entrepreneur }\end{array}$ & $\begin{array}{l}\text { Nature of } \\
\text { Business }\end{array}$ & $\begin{array}{l}\text { Number of } \\
\text { permanent } \\
\text { employees }\end{array}$ & $\begin{array}{l}\text { Years in } \\
\text { Operation }\end{array}$ & $\begin{array}{l}\text { Main } \\
\text { outputs }\end{array}$ & $\begin{array}{l}\text { Business } \\
\text { Location }\end{array}$ & Belief Expressions \\
\hline Male & $\begin{array}{l}\text { Sustainable } \\
\text { tourism firm }\end{array}$ & 6 & 2 & Tours & Namboole & God \\
\hline Female & $\begin{array}{l}\text { Fashion and } \\
\text { household } \\
\text { accessories } \\
\text { from used } \\
\text { drinking straws }\end{array}$ & 5 & 8 & $\begin{array}{l}\text { Mats, shoes, } \\
\text { belts }\end{array}$ & Kinawataka & $\begin{array}{l}\text { Holy Spirit, Roman } \\
\text { Catholic, Vision }\end{array}$ \\
\hline Female & $\begin{array}{l}\text { Efficient } \\
\text { energy cooking } \\
\text { stoves and } \\
\text { briquettes }\end{array}$ & 4 & 9 & $\begin{array}{l}\text { Energy } \\
\text { saving } \\
\text { stoves, } \\
\text { briquettes }\end{array}$ & Kasubi & Jesus, God, Church \\
\hline Female & Solar stoves & 5 & 6 & $\begin{array}{l}\text { Solar stoves, } \\
\text { chicken } \\
\text { brooders, } \\
\text { ovens }\end{array}$ & Rubaga & Church, God, Prayer \\
\hline Male & $\begin{array}{l}\text { Biodegradable } \\
\text { affordable } \\
\text { sanitary towels }\end{array}$ & 7 & 8 & $\begin{array}{l}\text { Sanitary } \\
\text { pads, } \\
\text { incinerators }\end{array}$ & Kawempe & Bible, God \\
\hline Male & Tree farmer & 8 & 17 & Saw logs & & God, \\
\hline Male & Fish farmer & 1 & 4 & Fish & Makerere & Allah \\
\hline Female & Charcoal trader & 1 & 20 & Charcoal & & God \\
\hline Female & Retail & 0 & 5 & Clothes & Owino & God \\
\hline Female & Trader & 0 & 4 & $\begin{array}{l}\text { Imported } \\
\text { Bags }\end{array}$ & Nakawa & God \\
\hline Female & Trader & 0 & 10 & $\begin{array}{l}\text { Food \& } \\
\text { Farming } \\
\end{array}$ & Makindye & God \\
\hline Female & Street Vendor & 0 & 4 & Charcoal & Mbuya & Allah \\
\hline Female & Trader & 0 & 8 & $\begin{array}{l}\text { Shoes \& } \\
\text { Farming } \\
\end{array}$ & New Park & God \\
\hline
\end{tabular}




\begin{tabular}{|c|c|c|c|c|c|c|}
\hline Female & Poultry & 0 & 4 & $\begin{array}{l}\text { Eggs \& } \\
\text { Chicken }\end{array}$ & Kireka & God \\
\hline Female & Market Vendor & 0 & 38 & \begin{tabular}{|l} 
Matooke \\
(Bananas)
\end{tabular} & Kireka & God \\
\hline Female & Art and Crafts & 0 & 25 & $\begin{array}{l}\text { African } \\
\text { crafts }\end{array}$ & Kireka & God \\
\hline Female & Tailor & 0 & 10 & \begin{tabular}{|l|}
$\begin{array}{l}\text { Tailor made } \\
\text { clothes }\end{array}$ \\
\end{tabular} & Kireka & Jesus, Holy Spirit \\
\hline Female & Restaurant & 5 & 11 & Food & Nakawa & God \\
\hline Female & Tailor & 0 & 4 & \begin{tabular}{|l|}
$\begin{array}{l}\text { Tailor made } \\
\text { clothes }\end{array}$ \\
\end{tabular} & Kireka & Jesus \\
\hline Female & Nursery School & 6 & 4 & Education & Mbuya & God \\
\hline Female & $\begin{array}{l}\text { Laundry \& } \\
\text { Baby Sitting }\end{array}$ & 0 & 4 & $\begin{array}{l}\text { Clean } \\
\text { clothes }\end{array}$ & Mbuya & God \\
\hline Female & $\begin{array}{l}\text { Food } \\
\text { Processing }\end{array}$ & 0 & 8 & Food & Kireka & God \\
\hline Female & Rosary making & 0 & 16 & Rosary & Makindye & Mother Mary, God \\
\hline Female & Retail Store & 1 & 20 & Groceries & Kireka & God \\
\hline Female & Trader & 0 & 10 & Food & Mbuya & God \\
\hline Female & Market Vendor & 0 & 10 & Fresh foods & Mbuya & Jesus, Born again \\
\hline Female & Market Vendor & 0 & 18 & Fresh foods & Zana & God \\
\hline Female & Weaving & 0 & 4 & \begin{tabular}{|l|}
$\begin{array}{l}\text { Handmade } \\
\text { Sweaters }\end{array}$ \\
\end{tabular} & Kireka & God \\
\hline Female & Crocheting & 0 & 4 & table clothes & Ndejje & God \\
\hline Female & $\begin{array}{l}\text { Food } \\
\text { Processing }\end{array}$ & 0 & 4 & \begin{tabular}{|l} 
Roasted \\
Maize
\end{tabular} & Ndejje & God \\
\hline Female & $\begin{array}{l}\text { Food } \\
\text { Processing }\end{array}$ & 0 & 10 & Food & Nakawa & God \\
\hline Female & Local Bar & 2 & 4 & $\begin{array}{l}\text { Locally } \\
\text { brewed } \\
\text { alcohol }\end{array}$ & Mbuya & Faith \\
\hline Female & Street Vendor & 0 & 4 & Fresh foods & Mbuya & Jesus, Born again \\
\hline Female & $\begin{array}{l}\text { Charcoal } \\
\text { Vendor }\end{array}$ & 0 & 8 & Charcoal & Mbuya & Allah, gods \\
\hline
\end{tabular}




\begin{tabular}{|c|c|c|c|c|c|c|}
\hline Female & Retail store & 2 & 6 & Groceries & Makerere & God \\
\hline Female & Retail Store & 0 & 14 & Groceries & Makerere & God \\
\hline Female & $\begin{array}{l}\text { Canteen } \\
\text { (Kiosk) }\end{array}$ & 2 & 5 & $\begin{array}{l}\text { Snacks and } \\
\text { tea }\end{array}$ & Ntinda & Faith, Anglican \\
\hline Female & Retail Store & 0 & 11 & Groceries & Makerere & Church \\
\hline Female & Weaving & 0 & 9 & Scarfs & Ntinda & Jesus \\
\hline Female & $\begin{array}{l}\text { Canteen } \\
\text { (Kiosk) }\end{array}$ & 1 & 10 & $\begin{array}{l}\text { Snacks and } \\
\text { tea }\end{array}$ & Namirembe & Faith \\
\hline Female & Trader & 0 & 7 & Clothes & Park & God \\
\hline Male & Welder & 6 & 16 & $\begin{array}{l}\text { House } \\
\text { fittings: } \\
\text { windows, } \\
\text { doors } \\
\end{array}$ & Kawempe & God \\
\hline Male & $\begin{array}{l}\text { Fabricator and } \\
\text { Importer }\end{array}$ & 12 & 60 & $\begin{array}{l}\text { Home } \\
\text { appliances } \\
\text { and Agro } \\
\text { machinery }\end{array}$ & Katwe & Allah \\
\hline Male & $\begin{array}{l}\text { Welder and } \\
\text { Mechanic }\end{array}$ & 1 & 28 & $\begin{array}{l}\text { Mufflers and } \\
\text { Exhaust } \\
\text { pipes }\end{array}$ & Kisenyi & God \\
\hline Male & $\begin{array}{l}\text { Welder and } \\
\text { trader }\end{array}$ & 3 & 8 & $\begin{array}{l}\text { Second-hand } \\
\text { food } \\
\text { processing } \\
\text { equipment } \\
\text { repair }\end{array}$ & Kisenyi & God, prayer, \\
\hline Male & Machinist & 1 & 14 & $\begin{array}{l}\text { Factory } \\
\text { equipment } \\
\text { and } \\
\text { machines } \\
\end{array}$ & Kisenyi & God \\
\hline Male & Welder & 3 & 15 & $\begin{array}{l}\text { House } \\
\text { fittings: } \\
\text { windows, } \\
\text { doors } \\
\end{array}$ & Kibuye & God \\
\hline
\end{tabular}




\begin{tabular}{l|l|l|l|l|l|l|} 
Male & $\begin{array}{l}\text { Foundry } \\
\text { specialist }\end{array}$ & 28 & 54 & $\begin{array}{l}\text { Agro } \\
\text { processing } \\
\text { machinery }\end{array}$ & Katwe & God, Christ \\
\hline Male & Blacksmith & 0 & 27 & $\begin{array}{l}\text { Charcoal } \\
\text { stoves }\end{array}$ & Owino & gods, forefathers \\
\hline
\end{tabular}




\section{Figure 1: Data Structure; Religious Beliefs shaping Entrepreneurial behaviour}

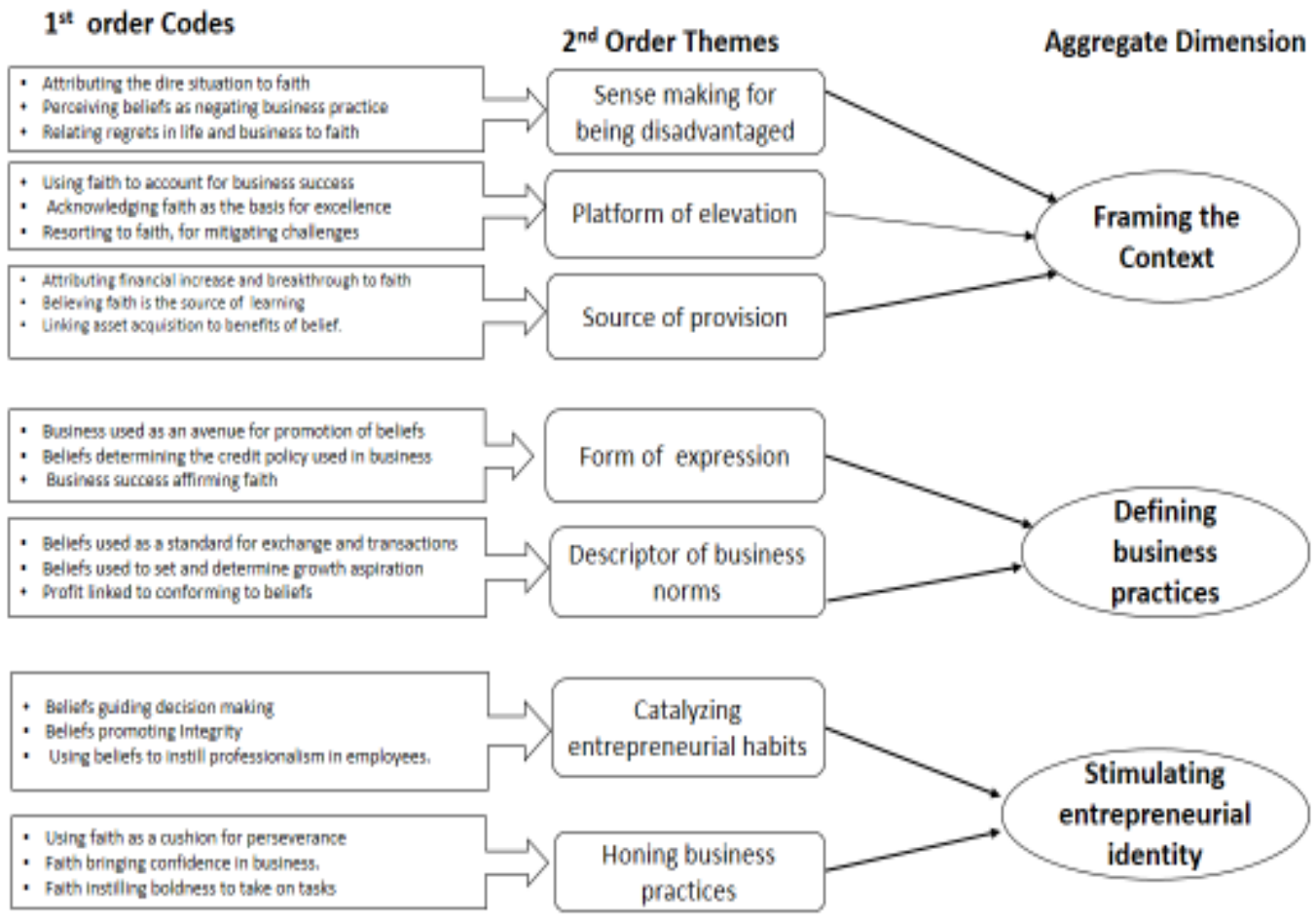

